\title{
Intercultural Communication and Social Harmony (Cultural Adaptation Case of "Queen of Silverware" Runi Palar in Ubud Bali)
}

\author{
Heru Ryanto Budiana ${ }^{1}$, Dian Wardhiana ${ }^{2}$, Centurion Chandratama Priyatna ${ }^{3}$ \\ \{heru.ryanto@unpad.ac.id ${ }^{1}$,dian.wardiana@unpad.ac.id ${ }^{2}$, centurion.priyatna@unpad.ac.id ${ }^{3}$ \} \\ 1,2,3 Universitas Padjadjaran, Indonesia
}

\begin{abstract}
Intercultural Communication Activities (KAB) are shown by how people adapt to other cultures. The ability of one's cultural adaptation as an open system to evolve with the surrounding social and cultural environment will, in turn, be able to build social harmony. Social harmony in society is reflected in the process of adaptation of Runi Palar, in the initial period of residence in Ubud, Gianyar, Bali. Runi, who transformed from a prima donna to a classical Javanese dancer, became a designer of silver jewelry so that today it is known as the "Queen of Silver Jewelry" in Indonesia - starting a silver jewelry business since 1966 in Bandung until it continues to grow and is widely known abroad, especially in the Japanese, European, American and of course Indonesian markets. After 35 years of living and developing a business in Bandung, in 2000, Runi and her husband decided to move to an area that was entirely new for them, Ubud, Bali. This initial period of stay in Bali is the reason why this research is focusing on the process of cultural adaptation by Runi with the local community as part of KAB activities. This research is conducted to find out how the activities of KAB Runi in building social harmony with the surrounding community. The research subject is Runi Palar. The object of this research is something related to the activities of KAB by Runi Palar in building social harmony with the people of Banjar Abiansemal, Lotunduh, Ubud, Gianyar, Bali. The results show that communication establishes an attitude of tolerance, mutual understanding, and respect in a very effective way amid cultural, ethnic, and religious differences in the domestic context. Values in the context of KAB can be used as guidelines in interacting with people of different backgrounds to build social harmony as it contains moral values in them.
\end{abstract}

Keywords: Intercultural Communication, Cultural Adaptation, Social Harmony, Tolerance, Mutual respect.

\section{Introduction}

Sotjawaruni Kumala Palar, better known as Runi Palar, was born in Pujokusuman, Yogyakarta, on May 26, 1946. Runi was married to Drs Adriaan Palar, a descendant of Minahasa, born in Bandung, November 14, 1936. A Bachelor of Fine Arts ITB graduated in 1966, majoring in Interior Design. Runi and Adriaan first met in New York, the USA, in 1964. They married on October 29, 1967, blessed with three children, one boy, and two girls. The first child Miranda Risang Ayu Palar, the second, Alvin Daniel Dipodi Palar, and the third, Xenia Dani Tajiati Palar [1]. 
Runi Palar is one of Indonesia's Silver designers that are well known both at home and abroad, dubbed the "Queen of Indonesian Silver Jewelry." Runi's talent with the world of silver jewelry flowed from his father, the late R.S. Tjokrosoeroso, an expert on Indonesian burnt silver crafts. The soul of Javanese art and culture also flows within Runi, because from childhood to age 22, she became a classical Javanese dancer at the Yogyakarta Palace, guided directly by Kanjeng Gusti Pangeran Hario Tedjokusumo, through this dance Runi traveled to various countries in order to introduce Indonesian culture [2 ]

Runi decided to quit dancing after marriage and focus on taking care of her small family. At the encouragement of her husband, Runi tried to work and pursue the field of fashion art and silver jewelry, the talent he obtained from his father. In 1977, Runi officially raised the CV. Runa Jewelry, which has the specific name Runa taken from the abbreviation name Runi and Adriaan. Runi's interaction with international culture continues when Runi markets its products in various countries and region in Japan, Europe, and America, through exhibitions [1].

After about 35 years of living in Bandung and working in the world of jewelry, which makes her famous not only in Indonesia but also internationally, in 2000, Runi and her husband decided to move to Bali. According to their first child, Miranda Risang Ayu [3], the main reason for their move was more on personal choices, where they tried to avoid the hustle and bustle of Indonesia's political world, which was still crowded after the reform era. Bali is chosen as it is a region far from the center of political power, the area of dreams and imagination, and is also known for its high-level silver craftsmanship.

Moving to Bali is indeed a kind of dream for Runi and her husband, but it becomes a rather "foreign" place as they start to adapt to the new environment. Moreover, they live in rural areas far enough from the city, precisely in Banjar Abiansemal, Lotunduh, Ubud, Gianyar, Bali. As migrants who settle in new areas with different cultural backgrounds from their native regions, require them to adapt to their environment, because how fast their adaptability significantly affects the relations with the local community going forward.

A custom or habit of each region is undoubtedly different, because of the diversity of tribes, races, and religions that exist in Indonesia's rich culture, including its customs. This different custom can be applied to the habits of Balinese people, in general, with its characteristics, a strong culture instilled by his ancestors from generation to generation until now.

Indonesian society is a multicultural society. The reality of differences or the existence of multicultural societies is the result of the long history of Indonesian civilization. As a reality, the interaction of people from different cultures cannot be avoided or denied. Therefore, it is essential to realize and apply effective intercultural communication in communicating in society as an effort to build lives in cultural diversity in harmony,

Social harmony existed if the differences in cultural backgrounds fused into one and interethnic groups that carry each culture can respect each other without cultural boxing, that is what was built by Runi and her husband when they first lived in Ubud, Bali.

Based on the description above, this paper aims to find out how the cultural adaptation that occurred in Runi Palar and her husband when they first lived in Bali to build social harmony with the local community in the perspective of intercultural communication, especially relating to the process of cultural adaptation in which related to the Theory of Accommodation Communication.

There are three contemporary approaches in studying intercultural communication, namely: (1) the social science (or functionalist) approach, (2) the interpretive approach, and (3) the critical approach. These approaches are based on different fundamental assumptions, namely: human nature, human behavior, and the nature of knowledge. Each of these assumptions contributes in a unique way to the understanding of the relationship between culture and 
communication. These approaches vary in their assumptions about human behavior, their research goals, their conceptualization of culture and communication, and their preferred methodologies [4].

This research uses the social science (or functionalist) approach. This approach assumes a describable external reality. It also assumes that human behavior is predictable and that the researcher's goal is to describe and predict behavior. Social science researchers assume that culture is a variable that can be measured, which suggests that culture influences communication in much the same way that personality traits do. The goal of this research, then, is focusing on how culture influences communication. One theory in this approach is The Communication Accommodation Theory [4].

Howard Giles and colleagues developed the Communication Accommodation Theory (CAT) in 1973. CAT elaborates on the human tendency to adjust their behavior while interacting. The reason behind this behavior is explained as to control the social differences between the interactants. People accommodate their communication activities to get approval and to set a positive image in front of the interactant. The environment in which they are interacting also affects communication behavior.

CAT is influenced by social psychology and is guided by four major assumptions: 1) While communicating, there will be similarity and difference in the speech and behaviour. The characteristics that people exhibit are based on our experiences and the cultural backgrounds that we grew up in, 2) A conversation is evaluated by understanding the perception of the speech and behaviour of the other. Through evaluation, people decide to accommodate and fit in, 3) The social status and belonging is determined by language and behaviours. While people communicate, they tend to accommodate the behaviours of those who are in a higher social status than them, and 4) Norms guide the accommodation process, which varies in the degree of appropriateness. Norms define the behaviours of people, and they are expected to act accordingly [5].

Accommodation will vary in terms of the level of suitability of the speaker performer and social norms. Social norms have an important role because they provide limits in varying degrees of accommodative behavior that is seen as desirable in communication. When someone faces a new culture, special abilities are needed to overcome cultural differences or cultural gaps in new environments, namely adaptation. Cultural adaptation is a process by which a person learns and understands new cultural rules and habits [4].

There are two forms of First Adaptation, Convergence, which is a strategy in which the actors involved in the conversation adapt to communicative behavior with each other. This process is selective and based on perceptions of other speaker actors. Second, Divergence, which is a behavior where the actors involved in the conversation do not show any similarities between one another. However, divergence is not a condition to negate the response to the interlocutor, but rather an attempt to dissociate the communicator who is the interlocutor [6].

This research uses a phenomenological approach that seeks to illustrate the meaning of a person's life experience or several people about a concept or phenomenon. Based on the essence of the experience, it will be fundamental and emphasize the intensity of consciousness, where experience consists of things based on memory, image, and meaning. Complementing the phenomenological approach with qualitative methods used to explore and understand the meaning derived from social problems by some individuals or groups [7]. With this approach, researchers are expected to explore what is happening and get a picture related to the cultural adaptation of Runi Palar in Bali. This type of research is a descriptive study that presents a detailed picture of a situation, social structuring, or linkages [8]. 


\section{Result and Discussion}

\subsection{Cultural Adaptation Process}

Runi and husband have decided to stay for a long time in Bali. They certainly need careful preparation to make it easier to stay in a new place, one of which is quite important is the preparation for facing cultural differences. Runi has a Javanese cultural background and was raised in the Keraton environment. Javanese culture is known as one of the cultures that uphold politeness in acting and speech and tends to uphold modesty [9]. Runi, before lives in Bali, has built some interactions with a variety of different cultures. As a dancer, she traveled to various countries, she took her study in Bandung, she often held exhibitions in various countries while pursuing her jewelry business, and even she also married Adrian, who was a descendant of Minahasa, even though he was born in Bandung.

The experience of interacting with different cultures will certainly be sufficient preparation to start interacting with the new cultural environment, namely the culture of the Balinese people. Runi also learns more about the customs, traditions, and culture of the Balinese people through communication with his friends who are from Bali. Also, the move of Runi and her husband to Bali was their dream to avoid the noise of the hustle and bustle of the political world and to be closer to their high-level silver craftsmen, so that when they could get land to live in Bali, they were very enthusiastic and excited.

Basically, in interacting with fellow human beings, both Javanese culture and Balinese culture have a similarity, namely mutual respect to build harmonious relationships. The life of the Balinese people has long been known as a society that underlies their daily lives based on culture. Issues of Hindu customs and religion are difficult to separate, it is integrated into Balinese culture[10]. Balinese culture is an expression of the relationship of Balinese interactions with the environment, as an effort to achieve welfare. A harmonious and balanced relationship with the environment is reflected in the concept of Tri Hita Karana which means "three causes of well-being" (Tri = three, Hita = prosperous, and Karana = cause), which consists of: parhyangan (spiritual environment), pawongan (social environment), and palemahan (physical environment). The three elements are inseparable unity [11].

The cultural paradigm of the Tri Hita Karana concept is the basis of how the Balinese develop patterns of adaptation between humans and their environment. Related to interaction with fellow humans, the concept of Pawongan explains that humans cannot live alone but always interact with other humans and at the same time, become part of their social system. One human must always maintain a harmonious relationship with other humans. In this framework, it is necessary to have a Sukerta Tata Pawongan system that includes social institutions that can guarantee the creation of harmonious relations between people. In a universal context, Sukerta Tata Pawongan reflects the high respect for human values, human rights, and peace between people. 


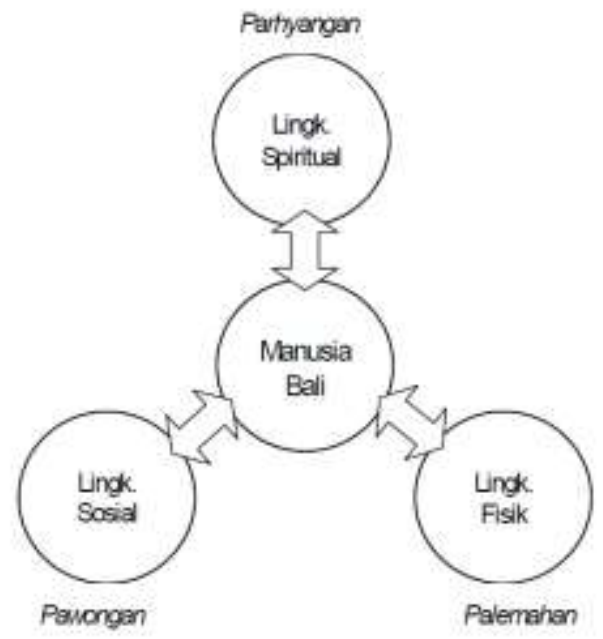

Figure 1. Balance of Relationship between Humans and Spiritual, Social, and Physical Environments [11].

Balinese culture imbued with Hinduism patterns of harmonious relations between humans and their fellow humans is reflected in the Tat Twam Asi concept, which means "you are me, and I am you." This concept implies love and solidarity in developing harmonious relationships between human beings. Harmonious relationships will be created if based on tolerance. Tolerance means mutual respect and mutual respect, which will foster a sense of brotherhood and harmony in life regardless of race, position, and other differences.

It is interesting to note that Runi and her husband understand that they will face cultural differences, and they are ready to learn with this new culture. This is slightly different from the three-stage process of adaptation formulated by Young Yun Kim (2001), namely stressadaptation-growth [12]. The first process is stress, where individuals who want to come to a new place are assumed to feel depressed and worried, which is not the case for Runi and her husband because the feelings of joy and enthusiasm are dominant.

Runi and husband also apparently went straight to the next process, namely smooth adaptation, because of the readiness they did. As for the third process, namely growth, Runi is in line with what was revealed by Kim (2001) that there is no word stop in an adaptation process. Every day they learn something new related to the culture in which they live.

According to Runi Palar [13], they began living in Bali in Banjar Abiansemal, Lotunduh, Ubud, by buying a plot of dry land, an area of approximately 2 hectares from the indigenous population at a relatively low price at that time, because landowners required money. At first they were confused in how to develop the concept of a place to live in the land, then they went to Panjuru Desa Pakraman (now called Adat Village) Abiansemal to convey their existence as new residents and plan to build a residence on the land while asking for input on the concept of place stay in accordance with local culture and customs.

Their communication shows the beginning of the stage of cultural adaptation as soon as they live there. They made some contacts with local community leaders in the neighborhood. Communication being established has made them begin to understand the local culture. This socialization activity, according to Kim (2001), is a stage of cultural adaptation, which is the 
basic process of communication. The process where mutual understanding between migrants and residents is known as enculturation.

The socialization carried out by Runi received an extraordinary response from the adat village, besides receiving them with open arms, the village also assisted in the process of housing construction by working together. The customary village mobilized the Banjar Abiansemal Ubud community of 30 men and women every day from 7 am to 12 noon to donate their time and energy during the construction process without being paid a penny, even if the community refused, because this cooperation becomes their custom and culture. Interestingly, the number of 30 people is still consistent until the end, if there is an absent, then it is replaced by other family members so that the number of people remains 30 .

\subsection{Building Social Harmony Through Communication Accommodation}

Referring to the conception of CAT, which has been described earlier, it is the intercultural adjustment or cultural adaptation that is the core of the CAT concept. The process of adaptation in a new environment is certainly not something easy, and it is because each has a different cultural background to start from. How does the cultural background, personal identity, the situation when communication occurs, and individual motivation can influence the accommodation process when someone is communicating with people who have different cultural backgrounds.

Modification as a form of accommodation or adaptation to achieve effective communication is usually called convergence. Whereas accommodation that tends to emphasize this difference is often called divergence. It can be seen that the accommodation strategy undertaken by Runi Palar and her husband, in general, is by convergence by making adjustments to build harmonious relationships. For example, Runi's husband is an architect, so that he may have a design concept for their residence. However, he chooses not to do that because they respected and valued the input of the local community to design the architecture and structure of residential buildings under the customs and culture of Bali. The conception of a house or residence that must be by the rules of Asta Kosala Kosali based on the philosophy of Tri Hita Karana.

Other adjustments, for example, carried out by Runi Palar as a form of respect and appreciation to the local community, were shown by giving a portion of their land as an access road for the community to go to the bathing location in the shower located behind their land. As one of the habits of Balinese, especially in the countryside to date, is both men and women are bathing in an open shower.

Runi Palar and husband also invited the area of their residence to be given offerings of Mesaiban every morning by the local community, especially at the exit of the house or the courtyard door. Meisaban itself is a routine ritual of the local community in the form of simple offerings, for example, a few grains of rice accompanied by incense and a splash of water as a form of gratitude for what is given by Hyang Widhi.

Convergence is indeed a selective process where one does not always choose to use it. Likewise, Runi Palar implements convergence on several things selectively depending on their needs when making adaptations. The choices made by Runi Palar show that communication between cultures is instrumental, where harmonization between them and the surrounding community is well developed. For example, when in 2001, they planned to open a jewelry museum (Runa Jewelry, House of Design, and Museum) as a showcase for Runi's works so far. They re-communicated the plan to the customary village leaders, and again the community worked together to contribute their time, energy and ideas to decorate and prepare all the needs 
of the opening of the museum unconditionally, even the community voluntarily provided traditional Balinese art to enliven the opening of the Runa museum.

In fact, according to Runi, social harmony is blessed by the universe by giving abundant blessings and positive prayers. At the opening of the museum there was an extraordinary event, where guests from abroad could be present, the museum was officially opened by the highest official of Bali, the Governor of Bali at that time Dewa Made Beratha, whereas according to Runi, he had never invited or asked the Governor to attend and open, because indeed he did not know him. Also, during the initial concept with an open concept in their residence, it was blessed with bright lights without the slightest rain, even though around other parts of Bali, it was raining heavily (because December is the rainy season).

They put aside their cultural attributes during the communication process by promoting equality. The situation that facilitates the establishment of communication between Runi and the local community is the standard norms and values of both Javanese culture and Balinese culture that teach about the need for harmony in society, which makes them tend to balance communication that occurs in various ways.

In general, the Balinese are very open with newcomers who can respect and behave politely, so they will also be kind and even provide assistance while still upholding their customs and culture. Runi and her husband held the principle that when they moved to Bali, they stayed there not to be Javanese or Manado in Bali. They try to respect the land in Balinese tradition.

\section{Conclusion}

Based on the description above, it can be concluded that the cultural adaptation carried out by Runi Palar and her husband when they decided to settle in Bali was relatively smooth because their background experience provided sufficient preparation to deal with cultural differences, so there was no feeling of hopelessness and depression due to difficulties in adjusting with a new culture. In cultural adaptation, there is an enculturation process that occurs at the time of socialization, where Runi Palar and her husband make adjustments to communication with the local culture. Adjustment is based on their understanding and experience as a way to carry out accommodation. This stage relates to the theory of accommodation that they apply, namely through convergence.

Intercultural communication that promotes the standard norms and cultural values of each, upholds mutual openness, mutual respect and tries to accept each other based on the belief that mutual influence is excellent and enriching, not destroying and not mutually defensive makes social harmony between Runi Palar and her husband with the surrounding community has remained awake until now.

\section{Acknowledgments}

Finally, we would like to thank all those who supported the completion of this article, especially Mother Runi Palar, as an extraordinary woman with all her success who remains unpretentious and remains willing to provide information on extraordinary experiences. We also would like to thank Runi Palar's first daughter, Ms. Miranda Risang Ayu, who was willing to take us to the place of Runi's mother in Ubud Bali and also to take the time to be interviewed. This article is far from perfect, but we hope to provide benefits not only to researchers but also to readers. For that reason, wise suggestions and constructive criticism are highly expected. 


\section{References}

[1] Redaksi, "Runi Palar: Metamorfosa Sang Penari Jawa," Money \& I Magazine, Denpasar, Nov-2017.

[2] A. Sulistyowati, "Runi Palar: Perjalanan Sang Desainer," Kompas, Jakarta, 2018.

[3] M. R. Ayu, "Wawancara, tanggal 10 October." 2019.

[4] J. N. Martin and T. K. Nakayama, Intercultural Communication In Contexts, 7th ed. New York: McGraw-Hill Education, 2018.

[5] R. West and L. H. Turner, Introducing Communication Theory: Analysis and Application, 4th ed. New York: McGraw-Hill Education, 2010.

[6] E. Griffin, A. Ledbetter, and G. Sparks, A First Look At Communication Theory. New York: McGraw-Hill Education, 2019.

[7] J. W. Creswell, Research Design: Qualitative, Quantitative And Mixed Methods Approaches, 4th ed. Thousand Oaks, CA.: Sage Publications, 2014.

[8] W. L. Neuman, Social Research Methods: Qualitative and Quantitative Approaches, 7th ed. London: Pearson Education Limited, 2013.

[9] A. Sholikhah, "Akulturasi Budaya Jawa Dengan Sunda (Studi Pada Masyarakat Dusun Grugak Desa Kutasari Kecamatan Cipari Kabupaten Cilacap),” Purwokerto, 2016.

[10] I. D. G. A. Pemayun and I. N. Meirejeki, "Harmonization of Tri Hita Karana And Cultural Tourism Bali,” J. Sos. dan Hum., vol. 6, no. 2, pp. 200-206, 2016.

[11] I. B. G. Pujaastawa, "Kebudayaan Bali." Makalah. Disampaikan Dalam Pelatihan Kehumasan Polri, Denpasar, 2014.

[12] Y. Y. Kim, Becoming Intercultural: An Integrative Communication Theory and CrossCultural Adaptation. USA: Sage Publications, 2001.

[13] R. Palar, "Wawancara, tanggal 25 September.” Denpasar, 2019. 